\title{
Analisis Dampak Pertapaan Ratu Kalinyamat terhadap Kondisi Sosial dan Ekologis Masyarakat Dukuh Sonder Era Modern
}

\author{
Muhammad Teguh Saputra \\ Universitas Negeri Jakarta, Jakarta, Indonesia \\ muhammadteguhsaputra_1404619041@mhs.unj.ac.id \\ Sylvia Putri Nadira \\ Universitas PGRI Semarang, Semarang, Indonesia \\ sylviaputri119@gmail.com
}

\begin{abstract}
This research is important with the following considerations: (1) There are still few studies that raise similar themes in terms of use value (2) Cultural heritage sites such as the Kalimat hermitage need to be maintained (3) Seeing the Kalimat hermitage from the side of its function is important in the modern era (4) Value The noble community began to be eroded by the current of modernization, so it was important to treat the site like the site that the researchers adopted. This study aims to determine the pragmatic side of the Ratu Kalinyamat Hermitage on the life of the Dukuh Sonder community around the Ratu Kalinyamat Hermitage. This goal can be determined by analyzing the impact of the hermitage on the social and ecological conditions of the people of Dukuh Sonder. Qualitative descriptive is the method that the researcher chooses in this research to explain complex social and natural events. As a test of validity, source triangulation is the method chosen. The results of this study indicate, from a social perspective, hermitage has an influence in forming consensus on the Sonder community and from an ecological perspective it has no effect on the Sonder community, it is the culture of the Sonder community that influences the Hermitage's environment so that it can be managed properly. So it can be concluded, the Hermitage of Ratu Kalinyamat is not eroded by modern currents because of the pragmatic and cultural dimensions inherent in society.
\end{abstract}

Keywords: Hermitage; Modern Era; Social Conditions; Ecological Condition 


\begin{abstract}
Abstrak
Penelitian ini penting dengan pertimbangan: (1) Masih sedikit penelitian yang mengangkat tema serupa dari sisi nilai gunanya (2) Situs cagar budaya seperti pertapaan kalinyamat perlu dijaga adanya (3) Melihat pertapaan kalinyamat dari sisi kefungsiannya menjadi penting di era modern (4) Nilai luhur di masyarakat mulai tergerus arus modernisasi, sehingga penting untuk merawat situs seperti situs yang peneliti angkat. Penelitian ini bertujuan untuk mengetahui sisi pragmatis dari Pertapaan Ratu Kalinyamat terhadap kehidupan masyarakat Dukuh Sonder di sekitar Pertapaan Ratu Kalinyamat. Tujuan tersebut dapat diketahui dengan menganalisis dampak pertapaan kalinyamat terhadap kondisi sosial dan ekologis masyarakat Dukuh Sonder. Deskriptif kualitatif adalah metode yang peneliti pilih dalam penelitian ini untuk menjelaskan peristiwa sosial dan alam yang kompleks. Triangulasi sumber sebagai uji validitasnya adalah metode yang dipilih. Hasil penelitian ini menunjukkan, dari segi sosial pertapaan berpengaruh dalam membentuk konsensus pada masyarakat Sonder dan dari segi ekologis pertapaan tidak berpengaruh apapun terhadap masyarakat Sonder, justru kebudayaan masyarakat Sonderlah yang memengaruhi lingkungan Pertapaan sehingga dapat dikelola dengan baik. Sehingga disimpulkan, Pertapaan Ratu Kalinyamat tidak tergerus oleh arus modern karena dimensi pragmatisnya serta budaya yang melekat pada masyarakat Dukuh Sonder.
\end{abstract}

Kata kunci: Pertapaan; Era Modern; Kondisi Sosial; Kondisi Ekologis

\title{
A. Pendahuluan
}

Era modern ini telah terjadi apa yang kita sebut dengan globalisasi. Globalisasi nyatanya membawa kita pada kehidupan serba praktis (Utomo 2016) dan pragmatis. Sesuatu dapat dikatakan layak dipertahankan atau dilepaskan berdasarkan nilai fungsinya terhadap keberlangsungan hidup manusia, jika sesuatu itu bernilai guna bagi kemajuan maka layak dipertahankan dan dirawat adanya, jika tak bernilai guna atau menghambat hidup manusia maka layak diseleksi adanya (Utomo 2016). Contohnya adalah metode kekerasan yang digunakan dalam mendidik, seiring berkembangnya ilmu pengetahuan dan zaman, metode mendidik mulai beralih dari metode kekerasan kepada metode yang humanis.

Konsekuensi dari modernisasi yang terjadi saat ini adalah hal-hal yang bersifat tradisional berpindah kepada hal-hal yang bersifat baru atau modern, tak terkecuali berubahnya budaya di Indonesia. Terjadinya perubahan budaya tersebut akan berdampak pada ditinggalkannya kearifan lokal yang ada (Setyaningrum, 2018), kearifan lokal yang berpotensi ditinggalkan salah satunya adalah kearifan lokal yang 
terkandung dalam situs cagar budaya berupa Pertapaan. Pertapaan menurut Kamus Besar Bahasa Indonesia (KBBI) adalah tempat orang bertapa atau bersemedi. Pertapaan merupakan salah satu bentuk dari situs cagar budaya yang banyak mengandung nilai. Nilai tersebut berupa estetika, sejarah, budaya, teladan tokoh yang berkaitan dengan Pertapaan, bahkan sampai pada nilai ekonomi, seperti terbukanya lapangan kerja karena ramainya pewisata yang berkunjung.

Masalahnya sebagian orang memandang Pertapaan hanya dari nilai di luar nilai gunanya (di luar dari sisi pragmatisnya), seperti pada penelitian Said tentang spiritualisme bertapanya Ratu Kalinyamat (Said, 2013) dan pada penelitian Rochman tentang menafsir simbol kecantikan, seksualitas, dan birahi bertapanya Ratu Kalinyamat (Utomo 2016), sehingga berpotensi pada ditinggalkannya pertapaan tersebut karena dianggap tak berguna bagi kemajuan kehidupan manusia. Hal tersebut disadari karena kurang diangkatnya pembahasan - pembahasan berkenaan dengan sisi lain dari nilai yang terkandung dalam suatu Pertapaan, yaitu nilai guna (sisi pragmatis) dari suatu Pertapaan. Selama ini pembahasan yang diangkat kebanyakan berkisar pada nilai magis, spiritual, simbolik, dan nilai - nilai lain di luar dari nilai guna, padahal memandang dari nilai gunanya berperan dalam mengembangkan hal - hal positif yang berkaitan dengan Pertapaan di era modern ini, untuk itu, topik yang peneliti angkat ini menjadi penting untuk dibahas.

Pertapaan yang peneliti angkat pada penelitian ini adalah Pertapaan Ratu Kalinyamat di Dukuh Sonder, Desa Tulakan, Kecamatan Donorojo, Kabupaten Jepara. Secara genealogi, Ratu Kalinyamat yang memiliki nama asli Retna Kencana merupakan Putri dari Sultan Trenggono (Raja ketiga Kesultanan Demak) sekaligus Cucu dari Raden Patah (Raja pertama Kesultanan Demak) (Utomo 2016). Sedari gadis Ratu Kalinyamat sudah dimandatkan menjadi Adipati Jepara. Ratu Kalinyamat kemudian menikah dengan Kyai Wintang atau Pangeran Hadirin dari Aceh. Julukan Pangeran Hadirin disematkan pada Kyai Wintang setelah menikah dengan Ratu Kalinyamat. Hadirin yang berarti hadir karena beliau hadir atau datang dari Aceh ke Jepara (Utomo 2016).

Tahun 1549 suami Ratu Kalinyamat, yaitu Pangeran Hadirin dibunuh oleh Arya Pinangsang (Utomo 2016) melalui utusannya. Pangeran Hadirin meninggal seusai menghadiri upacara pemakaman kakak kandung dari Ratu Kalinyamat yaitu Sunan Prawoto yang juga meninggal karena ulah Arya Penangsang (Utomo 2016). Dalam hal ini, Pak Mukhlisin selaku juru kunci Pertapaan Ratu Kalinyamat menuturkan:

"Diawali peristiwa terbunuhnya suaminya yaitu Sultan Hadirin dibunuh oleh pasukan Aryo Penangsang, kemudian Ratu Kalinyamat merasa sakit hati ingin membalas kematian dari sang pembunuh suaminya. Maka beliau mencari tempat 
untuk bertapa yaitu di sinilah tempatnya, kemudian beliau bermunajad, bertapa, bersemedi memohon kepada Allah agar sang pembunuh suaminya diberikan hukuman yang setimpal oleh Allah dan alhamdulillah doanya dikabulkan oleh Allah, Aryo Penangsang dibunuh oleh Sutowijaya." (Peneliti, wawancara dengan Juru Kunci pada 17 Juli 2021).

Pernyataan juru kunci tersebut didukung oleh beberapa literatur, di antaranya yaitu seperti pada penelitian Wardani, dkk. tentang nilai karakter religius cerita rakyat pertapaan ratu kalinyamat untuk siswa sekolah dasar (Utomo 2016) dan pada penelitian Said tentang spiritualisme bertapanya Ratu Kalinyamat (Utomo 2016). Disebabkan kesedihan yang mendalam akibat kehilangan sesuatu yang dicintai dan berharga bagi Ratu Kalinyamat, yaitu meninggalnya kakak kandungnya, Ratu Kalinyamat melakukan apa yang disebut Topo Wudo Sinjang Rambut atau bertapa telanjang dengan rambut terurai di bukit Danaraja, Dukuh Sonder, Desa Tulakan, Jepara (Waskitho, Hadi, \& Sulistyowati, 2013). Pertapaan tersebut dilakukan sebagai bentuk protes sekaligus bentuk pengharapan kepada Allah Swt. agar Arya Penangsang terbunuh. Tahun 1549 pula Arya Penangsang terbunuh dalam peperangan antara Pajang dengan Jipang, yang dalam peperangan tersebut pasukan Jipanglah yang mendapatkan kemenangan. Disebabkan Arya Penangsang terbunuh pada peperangan itu, momen tersebut dimanfaatkan oleh sekutu Ratu Kalinyamat untuk menobatkan Ratu Kalinyamat sebagai Penguasa Jepara (Utomo 2016).

Subjek penelitian yang penelitian ini adalah Juru Kunci yang sekaligus tokoh masyarakat setempat, yaitu Pak Mukhlisin yang sudah menjadi Juru Kunci Pertapaan Ratu Kalinyamat sejak tahun 2006, subjek tersebut peneliti pilih karena Pak Mukhlisin lah yang dapat menjelaskan pola perilaku masyarakat Dukuh Sonder terhadap Pertapaan Ratu Kalinyamat secara keseluruhan. Adapun masyarakat Dukuh Sonder peneliti pilih karena masyarakat Dukuh Sonder merupakan masyarakat yang lokasinya terdekat dengan lokasi Pertapaan Ratu Kalinyamat, sehingga relevan untuk mengukur kondisi sosial dan ekologis dari masyarakat yang dipengaruhi oleh Pertapaan Ratu Kalinyamat. Beberapa masyarakat Dukuh Sonder di sekitar Pertapaan Ratu Kalinyamat juga peneliti wawancarai, yaitu Bu Koti dan Pak Nas. Bu Koti dan Pak Nas peneliti pilih secara acak berdasar lokasi terdekat dari pertapaan dengan alasan yang telah dipaparkan sebelumnya. Peneliti juga secara langsung juga mengamati situasi di sekitar Pertapaan sebagai bentuk uji validitas dari metode triangulasi sumber.

Penelitian ini merupakan penelitian deskriptif kualitatif, yaitu melalui wawancara dan observasi sebagai metode yang peneliti pilih dalam menghimpun data. Selesai data terhimpun, kemudian peneliti menganalisisnya dengan dua pendekatan, yaitu teori sosial Jurgen Habermas berkenaan dengan teori komunikatifnya dan teori 
ekologi budaya berkenaan dengan bagaimana budaya berperan sentral dalam menetukan perilaku manusia terhadap lingkungannya. Dua pendekatan tersebut penulis pilih karena memiliki keterkaitan dalam menjelaskan bagaimana hubungan manusia, budaya, dan lingkungannya.

Jurgen Habermas lahir tahun 1929, beliau adalah pemikir kontemporer. Habermas berpendapat bahwa masyarakat komunikatif adalah masyarakat yang melakukan kritik dengan memberikan argumentasi. Teori tindakan komunikatif merupakan salah satu teorinya, Habermas berpendapat bahwa kritik hanya akan maju dengan landasan rasio komunikatif yang dimengerti sebagai tindakan komunikatif. Dijelaskan oleh Habermas, bahwa masyarakat pada hakikatnya komunikatif dan yang menentukan perubahan sosial bukanlah semata-mata karena berkembangnya kekuatankekuatan teknologi, melainkan proses belajar dalam dimensi praktis-etis (Sudrajat, 1988). Pernyataan tersebut sependapat dengan pendapat yang dikemukakan Iwan, menurutnya, proses dialektis masyarakat sebagai subjek maupun objek bagi tradisi kultural memiliki peran penting dalam konstruk tindakan komunikatifnya. (Iwan, 2014). Artinya dalam pandangan Habermas, penyebab dari terjadinya perubahan sosial adalah manusia, yaitu melalui interaksi atau kritik yang terjadi dalam satu masyarakat secara terus menerus.

Berkenaan dengan ekologi budaya, menurut Nur titik perhatian dari ekologi budaya adalah pada analisis struktur sosial dan kebudayaan, yang dengan hal tersebut perhatian kemudian baru diarahkan pada lingkungan, dengan syarat jika lingkungan memengaruhi pola-pola tingkah laku (Nur, 2021). Hal tersebut searah dengan pendapat yang dikemukakan Abdoellah bahwa berkenaan dengan ekologi budaya, faktor lingkungan tidak menentukan kemanusiaan (Abdoellah, 2017). Artinya adalah ekologi budaya adalah teori yang mencoba mengupas bagaimana populasi manusia dapat beradaptasi terhadap lingkungan alam di sekitarnya dengan menitikberatkan pada pola perilaku manusia dalam perannya sebagai inti kebudayaan. Berdasarkan itulah, budaya dalam teori ekologi budaya memiliki peran penting, yaitu sebagai penentu bagaimana manusia akan mengelola sumber daya alam di sekitarnya (Nur, 2021).

\section{B. Pembahasan}

\section{Cara Bertapa Ratu Kalinyamat Bagi Masyarakat Sekitar}

Sebelum menafsirkan bagaimana Pertapaan Ratu Kalinyamat berdampak pada kondisi sosial dan kondisi ekologis, pembahasan tentang bagaimana cara pandang masyarakat terhadap cara bertapanya Sang Ratu Kalinyamat juga penting. Dianggap penting karena sudah menjadi hal umum untuk diketahui bahwa perilaku atau sikap 
seseorang terhadap sesesuatu dipengaruhi oleh bagaimana sudut pandang orang tersebut dalam memandang sesuatu itu. Dianggap penting karena untuk menjelaskan kondisi sosial dan ekologis salah satu caranya dilakukan melalui pengamatan terhadap perilaku maupun pernyataan dari masyarakat terkait.

Ada dua versi yang populer dalam memaknai topo wudo sinjang rambut atau cara bertapanya Ratu Kalinyamat. Pertama, mengarah pada makna tekstual yaitu telanjang badan dengan rambut terurai. Kedua, mengarah pada makna interpretasi, yaitu bahwa yang dimaksud topo wudo sinjang rambut adalah bertapa dengan melepaskan segala pakaian berupa sifat keduniaan. Dua versi tersebut muncul secara bebas oleh masyarakat tanpa terikat oleh otoritas apapun (Said, 2013), sehingga, untuk dapat memetakannya, peneliti hanya mengungkap dua versi yang populer saja, sebagai pembanding, perlu diketahui pula ada beberapa versi lain di luar dua versi tersebut, misalnya versi sufistik yang menganggap topo udo adalah bertapa dengan bentuk kesufistikan tingkat tinggi, dan versi simbolis yang menyimbolkan topo udo sebagai bentuk dari perwujudan spiritualitas - erotis (Utomo 2016).
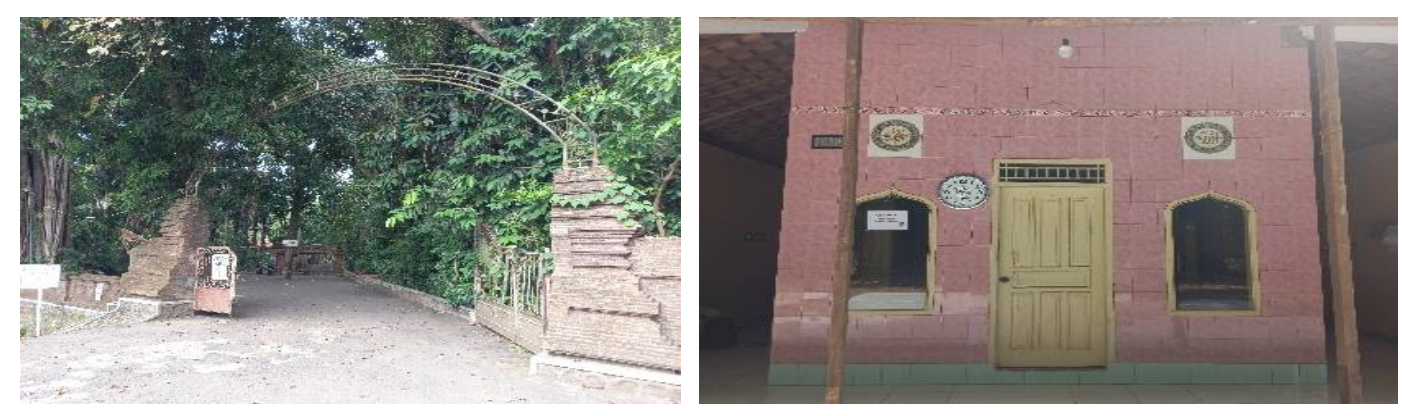

Gambar 1. Tampak depan Pertapaaan Gambar 2. Petilasan Pertapaan Ratu Kalinyamat

Namun, dari dua versi tersebut peneliti mencoba mengonfirmasi melalui wawancara yang kami lakukan pada Juru Kunci Pertapaan. Terlihat pada gambar pertama gerbang di mana kami memasuki kawasan pertapaan dan pada gambar kedua terlihat bahwa kami menjumpai bekas (petilasan) Pertapaan Ratu Kalinyamat yang sudah dibangun. Di sana kami bertemu dengan Juru Kunci dan bertanya kepadanya tentang bagaimana tanggapan masyarakat sekitar tentang topo udo sinjang rambut Sang Ratu Kalinyamat, kemudian beliau memaparkan,

"Topo Udo itu bukan berarti tapa telanjang tanpa busana itu nggak, udo itu dalam rangka bahasa jawa itu karna beliau melepaskan pakaian keraton memakai pakaian biasa, orang jawa itukan banyak sekali peribahasa, melepaskan busana keraton memakai pakaian rakyat biasa maka dianggap udo seperti itu, 
bukan berarti telanjang tanpa busana ya." (Peneliti, wawancara dengan Juru Kunci pada 17 Juli 2021)

Wawancara tersebut terlihat bahwa dalam memaknai topo udo masyarakat condong pada pengertian kedua, yaitu yang menginterpretasikan bahwa bertapanya Ratu Kalinyamat adalah dalam bentuk melepaskan sifat keduniaan atau bermewah mewahan, seperti dengan melepas pakaian keraton yang dikenakannya, kemudian berganti dengan memakai pakaian rakyat biasa. Hal tersebut senada dengan apa yang dikatakan Wardani, dkk. dalam penelitiannya bahwa dalam bahasa Jawa, udo tidak hanya berpengertian telanjang badan, namun juga berpengertian tidak memakai barang mewah seperti perhiasan dan pakaian yang bagus, artinya udo dalam hal tersebut hanyalah kiasan. (Utomo 2016).

\section{Analisis Kondisi Sosial Perspektif Jurgen Habermas}

Sudah dijelaskan sebelumnya bahwa dalam memaknai cara bertapa Ratu Kalinyamat, masyarakat menafsirkan dengan tafsir yang positif, sehingga hal tersebut mengindikasikan bahwa Ratu Kalinyamat merupakan sosok yang dihormati masyarakat sekitar Pertapaan. Pengaruhya pada penelitian ini adalah pada bagaimana masyarakat nantinya akan berpendapat pada suatu fenomena yang memiliki keterkaitan dengan kesakralan Pertapaan Ratu Kalinyamat.

Abrori berpendapat bahwa Habermas mengklaim bahwa sudah menjadi hal dasar sifat manusia untuk berkomunikasi (Abrori, 2016). Hal tersebut seperti yang dijelaskan Jurgen Habermas pada teori communicative actionnya bahwa sepanjang hidup manusia, hampir dipastikan bahwa seseorang akan terus berinteraksi, Habermas berkata dalam bukunya bahwa "Across various domains of interaction and over long periods (perhaps even over the space of a lifetime), we also speak of the rationality of a conduct of life." (Utomo 2016). Bagi peneliti, teorinya ini penting untuk membongkar bagaimana dampak dari relasi antara masyarakat di sekitar Pertapaan Ratu Kalinyamat dengan Pertapaan Ratu Kalinyamat itu sendiri sebagai bentuk dari situs cagar budaya yang kaya akan nilai.

Dalam hal kebudayaan, Mansur berkata bahwa kebudayaan merupakan karya dari nalar manusia (Utomo 2016). Maka dapat dikatakan bahwa bagaimana Pertapaan Ratu Kalinyamat akan diperlakukan tergantung pada bagaimana kebudayaan yang dibentuk masyarakat sekitar melalui komunikasi yang terjadi. Hal tersebut senada dengan fakta yang dikemukakan oleh Habermas, menurutnya komunikasi memiliki peran sentral dalam membentuk kebudayaan, Habermas berkata "The fact that social interaction in the domains important to cultural reproduction." (Utomo 2016). 
Di era modern ini informasi tersebar tanpa tersekat. Kabar nasional maupun internasional dapat dengan mudah diakses, sehingga masyarakat lokal pun tak dipungkiri menjadi masyarakat global, pola pikirnya sedikit banyaknya dipengaruhi oleh bagaimana perkembangan pola pikir global yang terjadi. Dengan hal itu, kita menjadi tau bahwa pola komunikasi masyarakat modern ini adalah pola komunikasi global (Utomo 2016). Menyambung dengan yang telah dijelaskan pada pendahuluan bahwa era modern membawa kita pada pragmatisme, sehingga tak aneh bila masyarakat sekitar dalam memperilakukan Pertapaan Ratu Kalinyamat sudah beralih.

Penelitian terdahulu, seperti pada penlitian yang dilakukan oleh Said tentang spiritualisme Ratu Kalinyamat (Utomo 2016), Pertapaan Ratu Kalinyamat ditanggapi sebagai situs yang memiliki kemagisan yang kuat, sehingga tak jarang situs seperti Pertapaan tersebut digunakan sebagai tempat untuk membuka aura seksual, mendapatkan kesaktian, kekuatan magis, ataupun mendapatkan keajaiban. Namun dewasa ini, masyarakat telah beralih lebih pada menilai situs Pertapaan Ratu Kalinyamat dengan tidak sepenuhnya terdogmatis oleh magis.

Hal tersebut terbukti dari pernyataan Juru Kunci Pertapaan saat kami Tanya tentang apakah masyarakat sungkan untuk merusak lingkungan di sekitar Pertapaan karena kesakralan Pertapaan. Namun, Sang Juru Kunci bukannya memberi pernyataan berkaitan dengan efek ghaib atau magisnya, tapi justru memberi pernyataan bahwa masyarakat tak berani merusak lingkungan di sekitar Pertapaan karena dianggap bernilai sejarah, lengkapnya yaitu,

"Ya karna kesadaran diri lah, karena ini dianggap sebagai situs sejarah maka masyarakat tidak berani untuk merusak, tidak berani untuk ya istilahnya malah justru ikut melestarikan karena dianggap seperti situs sejarah, satu - satunya sejarah dulunya Ratu Kalinyamat pernah bertapa disini, dirusak kan nanti keasrianya kan hilang terus kaalau situsnya hilang kan nanti kehilangan sejarah." (Peneliti, wawancara dengan Juru Kunci pada 17 Juli 2021).

Pernyataan tersebut diperkuat oleh wawancara kami kepada masyarakat sekitar, kami menanya tentang satu kasus yang baru saja terjadi menimpa salah satu bangunan di kawasan Pertapaan. Pertanyaan tersebut yaitu tentang tanggapan atas jatuhnya pohon di kawasan pemakaman yang menghancurkan salah satu bangunan di sekitar kawasan Pertapaan Ratu Kalinyamat, apakah ada kaitannya dengan mistis atau bagaimana. Namun, bukan jawaban dogmatis magis yang kami dapat, melainkan jawaban yang dapat dikatakan skeptis materialis,

"Ya kalau masalah itu kan gangerti ya nak, namanya kayu jatuh kan ga ngerti yang rusak kan gatau aku kan itu tumbangnya ya pagi jam 6 pagi kan ga ada yang tau. Jam 6 pagi, jam setengah 6 kan ada yang nyapu disitu pas jam 6 itu 
udah keluar tiba - tiba jatuh, lah aku baru buka di sini nah terus ada orang banyak nanya ada apa sih, lah itu ada pohon jatuh. Nah ceritanya gitu" (Peneliti, wawancara dengan Bu Koti pada 17 Juli 2021).

"Untuk mengatakan tanggapan seperti apa kita belum mengerti apa sebab dan akibatnya dari mana penyebab dan asal muasalnya kita nggak tau." (Peneliti, wawancara dengan Pak Nas pada 17 Juli 2021).

Berdasar pernyataan tersebut, terlihat bahwa subjek daripada langsung menghakimi akan terjadinya bencana ataupun terjadi suatu kemagisan karena tumbangnya pohon yang menimpa bangunan di sekitar makam, subjek justru berasumsi ada kerusakan pada kayu atau pohon sehingga menjadi penyebab jatuhnya pohon tersebut. Artinya bahwa subjek pola pikirnya mulai beralih pada pola pikir modern, meskipun begitu, kami menguji validitas pernyataan subjek dengan pertanyaan lanjutan, yaitu tentang apakah jatuhnya pohon tersebut ada kaitannya dengan kemagisan atau tidak. Faktanya, jawaban yang dilontarkan cukup konsisten dengan keskeptisannya, walaupun akhirnya tetap terlihat bahwa subjek tidak meninggalkan sama sekali asumsi bahwa ada kemungkinan tumbangnya pohon tersebut disebabkan oleh hal - hal yang terkait dengan kemagisan. Lengkapnya,

"Ya gatau, pohon tumbang ga ada angin ga ada hujan, nah jatuhnya jam 6 pagi ya tiba tiba saja gitu tumbang" (Peneliti, wawancara dengan Bu Koti pada 17 Juli 2021).

Terlihat dalam pernyataan tersebut, subjek berbicara seolah - olah ada penyebab di luar kekuatan yang kasat mata (angin dan hujan). Subjek dalam pernyataannya ingin mengomunikasikan pada peneliti bahwa pohon tersebut tumbang disebabkan oleh hal yang magis, namun di sisi lain subjek juga ingin mengomunikasikan bahwa hal yang memungkinkan juga jika tumbangnya pohon tersebut juga disebabkan oleh fenomena alam pada umumnya yang terjadi pada pohon tumbang, yaitu karena ada kerusakan pada kayu pohon.

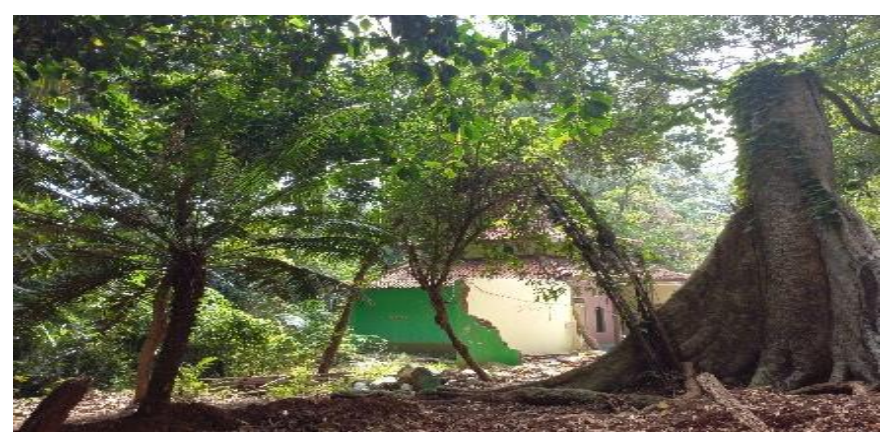

Gambar 3. Pohon Tumbang Menimpa Bangunan Petilasan 
Pernyataan tersebut diperkuat lagi oleh kegiatan sepasang remaja di kawasan Pertapaan Ratu Kalinyamat. Saat peneliti melakukan observasi, peneliti melihat secara langsung bahwa ada sepasang remaja dengan santainya memakan gorengan di sekitar Pertapaan, tepatnya di pinggir Sungai Pertapaan. Padahal kawasan Pertapaan oleh sebagian orang dipandang sakral, sehingga kegiatan yang tidak perlu, seperti memakan gorengan adalah hal yang sepatutnya tak dilakukan.

Hal tersebut dapat terjadi dan dapat dijelaskan oleh teori Jurgen Habermas melalui paradigma rasionalisasi dunia kehidupan yang berdasar pada teori kominkatifnya. Dalam paradigma rasionalisasinya tersebut Habermas menjelaskan bahwa terjadinya pemaknaan ulang terhadap kultur di masa modern yang menjamin situasi baru akan terjadi ini, tetaplah membutuhkan kelangsungan tradisi dan pengetahuan yang cukup untuk membentuk sebuah konsensus dalam praktik sehari-hari (Utomo 2016).

Artinya, terjadinya peralihan pola pikir masyarakat dari tradisional ke pola pikir modern seperti yang terjadi pada subjek penelitian itu tidak akan mengalami peralihan total, dalam arti subjek penelitian dalam beberapa bagian akan tetap mempertahankan pemikiran tradisionalnya, sehingga dapat dikatakan wajar apabila subjek penelitian dalam menyikapi tumbangnya pohon di sekitar Pertapaan Ratu Kalinyamat tersebut sebagian pernyataannya menyatakan tumbangnya pohon yang menimpa salah satu bangunan di sekitar Pertapaan kemungkinan disebabkan adanya kerusakan pada kayu pohon, namun di sebagian pernyataannya lagi menyatakan bahwa tumbangnya pohon tersebut disebabkan hal yang diluar nalar karena pohon tumbang secara tiba - tiba.

\section{Analisis Kondisi Ekologis Perspektif Ekologi Budaya}

Berdasar perspektif ekologi budaya, lingkungan tidak memengaruhi kondisi sosial (Utomo 2016). Artinya adalah faktor lingkungan atau alam sekitar tidak menentukan kemanusiaan (Utomo 2016). Justru sebaliknya, manusia sebagai makhluk sosial melalui kebudayaannyalah yang memengaruhi lingkungan secara langsung, sebagai inti kebudayaan, manusia dapat berlaku adaptif dalam menghadapi lingkungan di sekitarnya, sehingga, dapat diartikan dalam perspektif ekologi budaya bahwa kebudayaan setempat atau kearifan lokal memiliki peran sentral dalam menentukan bagaimana nantinya lingkungan akan diperlakukan dan dikelola oleh masyarakat, untuk mengetahui bagaimana hubungan masyarakat sekitar dengan lingkungan di kawasan Pertapaan, kami menanya pada Pak Mukhlisin selaku Juru Kunci tentang bagaimana sumber daya alam disekitar kawasan Pertapaan dikelola. Lengkapnya,

"Ya karena kesadaran diri lah, karena ini dianggap sebagai situs sejarah maka masyarakat tidak berani untuk merusak, tidak berani untuk ya istilahnya malah 
justru ikut melestarikan karena dianggap seperti situs sejarah, satu-satunya sejarah dulunya Ratu Kalinyamat pernah bertapa disini, dirusak kan nanti keasrianya kan hilang terus kaalau situsnya hilang kan nanti kehilangan sejarah.” (Peneliti, wawancara dengan Juru Kunci pada 17 Juli 2021).

Berdasar keterangan tersebut, untuk merusak lingkungan di sekitar Pertapaan memang tidak ada yang berani karena kesadaran diri, kemudian, peneliti menelusur lebih dalam dengan menanya pada $\mathrm{Bu}$ Koti selaku masyarakat sekitar dengan pertanyaan sejenis, subjek menjawab bahwa asal untuk kepentingan yang penting, seperti memetik tumbuhan di sekitar Pertapaan sebagai bahan untuk pengobatan itu tidak masalah, namun subjek memberi syarat harus dengan izin Sang Ratu Kalinyamat, lengkapnya,

"Tanaman obat yang dicari ada di situ, tapi begini nak, di sana ambil obat silahkan namun dengan perantara izin Bu Ratu Kalinyamat, misalnya mbah saya minta tolong minta doa dari panjenengan minta obat Gusti Allah Taala." (Peneliti, wawancara dengan Bu Koti pada 17 Juli 2021).

Izin tersebut hemat peneliti seminimalnya dapat dilakukan melalui ucapan berupa kata permisi dan lebih lengkapnya seperti yang dikatakan $\mathrm{Bu}$ Koti dalam wawancara. Akan tetapi, jika pengelolaan alam itu dengan tujuan yang dianggap tak penting seperti tujuan komersil dan tujuan pengambilan kayu pohon, maka hal tersebut dilarang.

Artinya adalah bahwa masyarakat turut merawat lingkungan di kawasan Pertapaan dengan tidak melakukan eksploitasi yang tidak diperlukan, sehingga menjadi hal penting untuk digaris bawahi adalah meskipun masyarakat hidup dalam era modernitas yang kental dengan sifat materialis, tapi mereka tetap dapat mengelola lingkungan di kawasan sekitar Pertapaan dengan baik.

Tentang bagaimana kondisi tersebut dapat terjadi, hal tersebut dapat dijelaskan oleh perpektif ekologi budaya. Karena ekologi budaya mengandalkan budaya sebagai hal yang sentral pengaruhnya dalam hubungan antara manusia dengan lingkungannya, maka penting untuk kita mengetahui bagaimana kondisi budaya yang ada pada masyarakat. Untuk mengetahui hal tersebut, kami menanya pada Juru Kunci tentang kebudayaan lokal yang ada di sekitar Pertapaan Ratu Kalinyamat ini, setelah ditelusuri, ternyata terdapat hari di mana hari tersebut Pertapaan Ratu Kalinyamat ramai dikunjungi oleh pengunjung dari berbagai latar belakang dan dari berbagai daerah, hari tersebut adalah Jumat Wage. Berdasar keterangan Juru Kunci, kedatangan pengunjung ke Pertapaan dengan berbagai tujuan, dari yang sekedar berkunjung, berdoa, berziarah, sampai dengan bertawasul. 
Berdasarkan kondisi budaya tersebut, dapat dikatakan bahwa dalam hal kesakralan, nyatanya Ratu Kalinyamat memiliki pengaruh yang besar sehingga banyak pengunjung yang datang khususnya pada Jumat Wage seperti yang dijelaskan sebelumnya. Berdasar keterangan Juru Kunci, yang datangpun tak hanya dari kalangan orang biasa, dari kalangan pejabat, artis, dan kyai juga berkunjung ke Pertapaan Ratu Kalinyamat dengan tujuan yang telah disebutkan pada paragraf sebelumnya. Jatuhnya pohon yang menimpa bangunan di sekitar pertapaanpun menurut Juru Kunci tak berpengaruh pada intensitas kesakralan Ratu Kalinyamat, menurutnya bangunan hanyalah sekedar bangunan, maksudnya bangunan tersebut hanyalah buatan manusia, sedangkan kesakralan adalah hal lain yang berdiri sendiri.

Berdasarkan budaya masyarakat sekitar yang telah dijelaskan sebelumnya, terlihat bagaimana masyarakat sekitar memperilakukan Pertapaan. Mereka menganggap sakral, sehingga mereka berkunjung dengan tujuan berdoa, berziarah, dan bertawasul atau berdoa kepada Allah Swt. melalui perantara Pertapaan Ratu Kalinyamat. Berdasar kondisi sosial yang dijelaskan sebelumnya, kita juga tau bahwa dalam berperilaku sosial, masyarakat tetap menyakralkan Pertapaan walaupun dalam pemikirannya cenderung ke arah modernitas.

Berdasarkan dua kondisi tersebut, yaitu kondisi sosial dan budaya, telah jelas bahwa artinya faktor yang memengaruhi masyarakat dapat dengan baik dalam mengelola lingkungan adalah faktor budaya masyarakat di sekitar pertapaan. Budaya seperti meminta izin, berdoa, dan sebagainya yang dilakukan dalam Pertapaan mengindikasikan bahwa mereka menyakralkan Pertapaan tersebut, sehingga dengan kesakralan tersebut menyebabkan terjadinya pembatasan dalam masing-masing individu dalam masyarakat untuk tidak berlaku buruk pada lingkungan di kawasan sekitar Pertapaan.

\section{Simpulan}

Era modern ini telah membawa manusia sebagai anggota dari masyarakat menuju sifat-sifat materialis pragmatis, sehingga menilai sesuatu berdasarkan dari sisi kefungsiannya dan keuntungannya. Di sisi lain, manusia juga merupakan makhluk komunikatif yang sepanjang hidupnya berinteraksi sosial, sehingga hal-hal yang bersifat tradisional secara turun temurun diwariskan tidak dapat digantikan sepenuhnya oleh modernitas. Era modern ini Pertapaan Ratu Kalinyamat yang merupakan salah satu situs cagar budaya nyatanya dilihat masyarakat dalam dua dimensi, yaitu dimensi pragmatis sehingga dianggap memiliki nilai sejarah dan nilai teladan dari ketokohan Sang Ratu Kalinyamat, sekaligus dimensi magis sehingga dianggap sakral bagi masyarakat sekitar. Pertapaan Ratu Kalinyamat tidak tergerus oleh arus modern karena dimensi pragmatis 
serta budaya yang melekat pada masyarakat. Berdasar analisis yang dilakukan melalui teori tindakan komunikatif Jurgen Habermas serta ekologi budaya didapatkan hasil bahwa Pertapaan Ratu Kalinyamat di era modern ini memengaruhi kondisi sosial dalam hal turut andil dalam membentuk konsensus yang ada pada masyarakat, yang di mana konsensus tersebut digunakan masyarakat dalam membentuk budaya pada masyarakat dukuh Sonder, sedangkan di sisi ekologi budaya Pertapaan Ratu Kalinyamat tidak berdampak apa-apa, yang memberi dampak justru adalah manusia sebagai inti kebudayaan, sehingga, kebudayaan yang dibentuk masyarakat berperan dalam membentuk perilaku masyarakat yang konservatif, sehingga dalam hal mengelola lingkungan Pertapaan, masyarakat dapat mengelolanya dengan baik, seperti dengan tidak merusak lingkungan di sekitar Pertapaan dan dengan tidak memanfaatkan tumbuhan di sekitar kawasan Pertapaan tersebut, kecuali benar-benar dibutuhkan.

\section{DAFTAR PUSTAKA}

Abdoellah, O. S. (2017). Ekologi Manusia dan Pembangunan Berkelanjutan. Jakarta: Gramedia.

Abrori, A. (2016). "Refleksi Teori Kritis Jurgen Habermas atas Konsesus Simbolik Perda Syariah." AHKAM : Jurnal Ilmu Syariah, 16(1), 71-88.

Habermas, Jurgen, The Theory of Communicative Action: Reason and Rationalization, Boston: Beacon Press, 1984.

Iwan, I. (2016). "Menelaah Teori Kritis Jurgen Habermas." Edueksos: Jurnal Pendidikan Sosial \& Ekonomi, 3(2), 145-165.

Mansur, R. (2019). "Sumbangsih Kebudayaan Pada Manusia Dalam Prespektif Islam." Vicratina: Jurnal Pendidikan Islam, 4(1), 114-124.

Mekarisce, A. A. (2020). "Teknik Pemeriksaan Keabsahan Data pada Penelitian Kualitatif di Bidang Kesehatan Masyarakat." Jurnal Ilmiah Kesehatan Masyarakat: Media Komunikasi Komunitas Kesehatan Masyarakat, 12(3), 145151.

Mi'ah, A. (2013). "Pemikiran Nurcholis Madjid tentang Modernisasi Sistem Pesantren." Skripsi. Surabaya: IAIN SUNAN AMPEL SURABAYA.

Nur, G. N. S. (2021). "Ekologi Budaya sebagai Wawasan Pokok dalam Pengembangan Masyarakat untuk Pembangunan Berkelanjutan di Indonesia." Jurnal TAMBORA, 5(1), 27-33.

Purwaningtyas, F. (2018). Pola Literasi Informasi dan Media sebagai Metode Penelusuran Informasi. IQRA : Jurnal Ilmu Perpustakaan Dan Informasi (eJournal), 12(2), 1-10.

Purwati, A. (2019). "Implementasi Pendidikan Seni dalam Mempertahankan 
Karakteristik Bamgsa Pada Generasi Milenial." Al 'Ulum: Jurnal Studi Islam, 15(1), 1-10.

Rejeki, S. K. (2019). "Peranan Ratu Kalinyamat dalam Perkembangan Kota Jepara (1549-1579)." Sosio E-Kons, 11(2), 174-182.

Ri'aeni, I. (2015). "Penggunaan New Media dalam Promosi Pariwisata Daerah Situs Cagar Budaya di Indonesia." Jurnal Komunikasi, 9(2), 187-197.

Rochanah, \& Mustolehudin. (2019). "Spiritualisme Ratu Kalinyamat: Menelusuri Kearifan Lokal Tradisi Baratan di Desa Kriyan Kalinyamatan Jepara." Al-Qalam, 25(1), 147-160.

Rochman, K. L. (2015). "Spiritualitas-Erotis Ratu Kalinyamat (Menafsir Simbol Kecantikan, Seksualitas dan Birahi yang Terkait dengan Mitos Topo Wudho, Wit Jati Bolong dan Pelacur Keraton Terhadap Pilihan Hidup Pragmatisme-Hedonis Perempuan Jepara)." Jurnal Penelitian Agama, 16(1), 50-67.

Said, N. (2013). "Spiritualisme Ratu Kalinyamat: Kontroversi Tapa Wuda Sinjang Rambut Kanjeng Ratu Di Jepara Jawa Tengah." El-HARAKAH: Jurnal Budaya Islam, 15(2), 105-123.

Setyaningrum, N. D. B. (2018). "Budaya Lokal di Era Global." Ekspresi Seni: Jurnal Ilmu Pengetahuan Dan Karya Seni, 20(2), 102-112.

Sudrajat, Ajat. (1988). Jurgen Habermas: Teori Kritis dengan Paradigma Komunikasi. Retrieved http://staffnew.uny.ac.id/upload/131862252/penelitian/Jurgen+Habermas++ Teori + Kritis + dengan + Paradigma + Komunikasi.pdf

Wardani, E. R., Fathurohman, I., \& Kuryanto, M. S. (2021). "Nilai Karakter Religius Cerita Rakyat Pertapaan Ratu Kalinyamat untuk Siswa Sekolah Dasar." PROGRES PENDIDIKAN, 2(1), 48-54.

Wasitohadi, W. (2012). "Pragmatisme, Humanisme dan Implikasinya Bagi Dunia Pendidikan di Indonesia." Satya Widya, 28(2), 175-190.

Waskitho, H., Hadi, P. K., \& Sulistyowati, R. (2017). "Realita Konflik Politik dan Konflik Batin dalam Novel Ratu Kalinyamat Tapa Wuda Asinjang Rikma Karya Sri Wintala Achmad." Widyabastra: Jurnal Ilmiah Pembelajaran Bahasa Dan Sastra Indonesia, 1(1), 1-9.

Wirawan, I. B. (2012). Teori-teori Sosial dalam Tiga Paradigma: Fakta Sosial, Definisi Sosial, dan Perilaku Sosial. Jakarta: Kencana Prenada Media Grup. 